\title{
Pine Needle Oil Pinus mugo
}

National Cancer Institute

\section{Source}

National Cancer Institute. Pine Needle Oil Pinus mugo. NCI Thesaurus. Code C107348.

The essential oil of Pinus mugo. Mugo pine oil is used primarily for its aroma but is also used in massage oils. 